\title{
Safety of antitumour necrosis factor (anti-TNF) therapy in patients with chronic viral infections: hepatitis $C$, hepatitis $B$, and HIV infection
}

\author{
L H Calabrese, N Zein, D Vassilopoulos
}

Ann Rheum Dis 2004;63(Suppl II):ii 18-ii24. doi: 10.1136/ard.2004.028209

Tumour necrosis factor $\alpha$ (TNF $\alpha$ ) is a pivotal cytokine in host defences with broad ranging effects on the innate and adaptive immune systems. Clinically, TNF $\alpha$ inhibitors have demonstrated remarkable efficacy in a wide range of autoimmune and inflammatory disorders but clearly at the cost of heightened susceptibility to a variety of infections in those treated with these agents. Most reports to date have described increased susceptibility to intracellular pathogens in patients with underlying chronic viral infections, but little in the way of adverse event reporting in these patients has occurred. While the reported experience to date is rather limited, TNF $\alpha$ inhibitors have displayed a reasonable safety profile in the setting of some chronic viral infections and in certain circumstances have demonstrated adjunctive activity in the treatment of these infections. Given the high prevalence of chronic viral infections in patients who are candidates for anti-TNF therapy and the potential for these agents in the treatment of chronic viral illness, additional studies are urgently needed to assess the risks and benefits of such therapy in these populations.

$\mathrm{T}$ umour necrosis factor $\alpha(\mathrm{TNF} \alpha)$ is a key cytokine in the integrated host defence system against infectious diseases. Given the far reaching effects of TNF $\alpha$ on both the innate and adaptive limbs of immunity it is not surprising that disruption of TNF $\alpha$ signalling pathways in animals leads to increased susceptibility to a variety of pathogens, in particular, those known to survive intracellularly. ${ }^{1}$ While clinical trials of these agents in a number of autoimmune diseases generally did not note increased susceptibility to typical or opportunistic infections, postmarketing analysis has clearly demonstrated an increased susceptibility to infections especially those caused by Mycobacterium tuberculosis, atypical mycobacteria as well as other organisms. ${ }^{2}$ The subject of infections and anti-TNF directed therapy has been recently reviewed. ${ }^{3}$

Despite these data on TNF $\alpha$ inhibition and heightened susceptibility to bacterial, fungal, and mycobacterial infections, relatively little has been described regarding the safety of these agents in the setting of chronic viral infections. Recent findings have demonstrated that TNF $\alpha$ mediated pathways play a critical role in regulating the molecular interactions between cellular and viral factors within infected cells and that many viral pathogens have learned to exploit the TNF pathway, using it to escape control and favour their spread. ${ }^{4}$

Viral diseases in general have three patterns of infectivity. Acute infections such as influenza appear to be self-limited disease whereby the host defences ultimately prevail and eliminate the pathogen. Herpes viral infections such as herpes simplex type 1 and 2, Epstein-Barr virus, and varicella zoster among others display a period of acute primary infection followed by a prolonged or lifelong period of latency whereby the host defence system keeps the pathogen in check. Failure of such immunological control involves reactivation, often with a different expression of disease (that is, dermatomal zoster). Finally, a few viral pathogens have the capacity to cause a primary infection and then remain in a persistent replicative state for the remainder of the life of their host. A relatively small number of viral agents are capable of such a pattern of disease, but these include hepatitis B and C viruses (HBV and HCV) and the human immunodeficiency virus (HIV) types 1 and 2. Given that these agents are prevalent worldwide, infecting an estimated half a billion patients, it is natural to question what effect inhibition of TNF $\alpha$ has on the natural history and clinical expression of these agents. In this report we provide a brief description of the epidemiology, clinical features, and potential role of TNF $\alpha$ in the pathogenesis of three of the most common and clinically significant chronic viral infections (HCV, HBV, and HIV) that may occur in patients requiring TNF $\alpha$ inhibitory therapy. In addition we review the published experience on the effects of TNF $\alpha$ inhibition in such patients on the infections themselves. Lastly, we present our thoughts on how to approach patients with these chronic viral infections who may require TNF $\alpha$ inhibitor therapy.

\section{HEPATITIS C}

Epidemiology and current therapy of HCV infection

A major scientific breakthrough occurred in 1989 with the cloning of the HCV viral genome by Houghton and associates at the Chiron Corporation in California. ${ }^{45}$ Shortly after the discovery of HCV, it became apparent that this newly identified virus was the principal aetiologic agent for non-A non-B hepatitis. The rapid development of sensitive serological assays for HCV antibodies led to a large decrease in the incidence of transfusion associated hepatitis, but it raised many important questions about the burden of this viral infection and about the treatment of those already infected. It is now firmly believed that HCV infection is associated with substantial morbidity and mortality and that it clearly represents a global public health challenge.

$\mathrm{HCV}$ is a bloodborne pathogen that appears endemic in most areas of the world and is estimated to infect nearly 200 million people worldwide. HCV infection occurs in patients of

\footnotetext{
Abbreviations: ALT, alanine aminotransferase; CTL, cytotoxic $T$ lymphocyte; HAART, highly active antiretroviral therapy; HBV, hepatitis $B$ virus; $H C C$, hepatocellular carcinoma; $H C V$, hepatitis $C$ virus; HIV, human immunodeficiency virus; NHANES, National Health and Nutrition Examination; SVR, sustained viral response; TNF, tumour necrosis factor
} 
both sexes, and all ages and races. ${ }^{6}$ Most accepted figures of the prevalence of HCV in the USA are derived from the Third National Health and Nutrition Examination (NHANES III), a national survey of non-institutionalised civilians, conducted between 1988 and $1994 .^{7}$ Since the NHANES III is a population based household survey, it is likely to underestimate the prevalence of HCV in the USA given the high prevalence of HCV antibodies in incarcerated, homeless, and institutionalised individuals.

On the basis of the NHANES III data (21 000 people were tested for HCV), an estimated 3.9 million (1.8\%) Americans were infected with HCV, and of this group 2.7 million (74\%) were estimated to have chronic infection associated with HCV viraemia (detectable serum HCV RNA). ${ }^{8}$ The NHANES III survey also outlined racial differences in the prevalence of HCV infection. The rate of prevalence of HCV antibodies in African Americans was more than twice that in Caucasian Americans. The highest observed prevalence of HCV was 9.8\% among black men between the ages of 40 and 49 years. ${ }^{7}$ Data from the US Centers for Disease Control (CDC) suggests that annual incidence of HCV has declined from an estimated 23000 new cases per year in the late 1980s to approximately 3500 new cases per year in the 1990s. Although the incidence of HCV may be decreasing, the prevalence of liver disease associated with chronic HCV infection including liver failure and hepatocellular carcinoma (HCC) is rising. ${ }^{8}$

The rate of chronicity after acute HCV infection has not been well established but is believed to exceed $70 \%{ }^{9}$ In the setting of chronic HCV, several long term complications including cirrhosis, endstage liver disease, and HCC may develop although significant biological variation has been demonstrated among infected patients. It has been estimated that $20 \%$ of patients with chronic HCV developed cirrhosis after 20 years of infection. ${ }^{9}$

In patients with chronic HCV treatment with recombinant interferon (IFN) or a combination of recombinant IFN and ribavirin is effective and has been approved by the US Food and Drug Administration. The highest response rates, defined as sustained viral eradication or response (SVR), have been achieved with the pegylated formulation of interferon (PEGIFN) in combination with ribavirin. ${ }^{10-12}$ Using PEG-IFN/ ribavirin as therapy, SVR rates have been achieved in over $80 \%$ of treatment naive patients infected with HCV genotype 2 or 3 and in $42-46 \%$ of patients with chronic HCV genotype 1 infection. Given the multiple limitations of current therapy for chronic HCV and its inadequate efficacy in those with HCV genotype 1 infection, novel therapeutic approaches need to be developed.

\section{Mechanisms of viral eradication and refractoriness during therapy in patients with HCV infection and the role of TNF $\alpha$}

A number of predictors of response to therapy in patients with HCV infection (age, sex, body weight, race, and hepatic histology) have suggested a central role for host factors in the outcome of therapy. ${ }^{13}{ }^{14}$ An imbalance in the circulating $\mathrm{T}$ helper (Th 1 and Th2) cell cytokine responses has been implicated in susceptibility to HCV and in progression of liver disease in cases of chronic infection. In acute self-limited HCV infection, circulating Th cells have been shown to predominantly produce IFN $\gamma$, suggesting a Thl-like response. ${ }^{15}$ Similarly, while patients who are able to spontaneously clear acute HCV infections have a strong Th 1 response without detectable Th 2 response, those who become chronically infected have a dominant Th 2 response. ${ }^{16}$

During therapy with PEG-IFN or non-PEG-IFN, the overall HCV specific CD4+ T cell responses in those with SVR have been shown to be greater in frequency, vigour, and breadth compared with non-responders. ${ }^{17}$ None of the patients who failed to mount an early, significant, HCV multispecific, CD4+ $\mathrm{T}$ cell response during therapy achieved SVR suggesting that early modification of the frequency, specificity, and magnitude of the CD4+ response by therapy may be a critical determinant of viral clearance and outcome of treatment. ${ }^{17}$ Interestingly, two earlier studies showed that the addition of ribavirin to IFN alfa-2b modulates HCV specific CD4+ responses in favour of a Th 1 response with promotion of IFN $\gamma$ production and suppression of IL-10. ${ }^{18} 19$ The maximal induction of HCV specific T cell reactivity occurred between four and 12 weeks of therapy with clear differences between the cytokine profiles of treatment responders and nonresponders suggesting that this may be an important mechanism for viral decline during therapy and subsequently viral clearance. In a recent study, ${ }^{17}$ it was demonstrated that the increased efficacy of PEG-IFN alfa-2a over non-PEG-IFN alfa-2a is related, at least in part, to its greater ability to induce and maintain a significant HCV specific CD4+ Th 1 response.

Despite being a Th 1 cytokine, TNF $\alpha$ has been implicated in refractoriness to IFN therapy in HCV patients. TNF $\alpha$ plays a major role in the host's immunomodulatory response to infective agents, including pathogenesis of sepsis, progression of acquired immunodeficiency syndrome (AIDS), and a number of inflammatory diseases. ${ }^{20} \mathrm{TNF} \alpha$ inhibitors block TNF mediated effects such as lethality in septic shock, replication of HIV in vitro, and others. ${ }^{21}$ It has been well established that TNF $\alpha$ is increased in HCV infection. ${ }^{22-24}$ Patients with high titres of proinflammatory cytokines, particularly $\mathrm{TNF} \alpha$, before treatment with IFN are less likely to respond to treatment compared with those with lower levels of these cytokines. ${ }^{25}$ Persistence of these cytokines even when HCV RNA becomes undetectable during treatment has been shown to be associated with relapse. Tsai and coworkers ${ }^{16}$ showed that treatment with IFN in patients with chronic HCV resulted in significant and rapid increase in soluble TNF receptor p55 (TNFsRp55), which is a natural inhibitor of $\mathrm{TNF} \alpha$, coupled with a great decline in serum $\mathrm{TNF} \alpha$ to undetectable levels in responders. Larrea et al ${ }^{26}$ analysed the expression of TNF $\alpha$ genes in patients with chronic HCV. They found that the presence of HCV RNA in the liver or in peripheral blood mononuclear cells (PBMC) is associated with increased $\mathrm{TNF} \alpha$ gene expression and that enhanced TNF $\alpha$ synthesis may contribute to refractoriness to the therapeutic actions of IFN. These data, although descriptive, clearly suggest a potentially vital role for TNF $\alpha$ in refractoriness to IFN therapy in HCV patients. The mechanisms by which TNF $\alpha$ induces refractoriness to IFN in these patients remain to be worked out although existing data suggest an inhibitory effect of $\mathrm{TNF} \alpha$ on $\mathrm{T}$ cell proliferation and activation. Exposure to TNF $\alpha$ impaired production of Th 1 cytokines following antigen stimulation. In patients with rheumatoid arthritis, treatment with a chimeric anti-TNF monoclonal antibody restored the diminished proliferative responses of PBMC to mitogens and recall antigens suggesting reversibility of this process ${ }^{27}$ Treatment with TNF $\alpha$ monoclonal antibodies in patients with rheumatoid arthritis resulted in accumulation of Th I CD4+ T cells in peripheral blood ${ }^{28}$ Similarly, treatment with soluble TNF $\alpha$ receptors (etanercept) in patients with rheumatoid arthritis increased peripheral $\mathrm{T}$ cell reactivity to several microbial antigens with a significant increase in the production of IFN $\gamma{ }^{29}$

In summary, although TNF $\alpha$ blockade suppresses certain elements of the immune system, it may also stimulate certain aspects of the antimicrobial defence mechanism by increasing the reactivity of peripheral $\mathrm{T}$ cells to specific antigens. Whether modulating these biologic effects of $\mathrm{TNF} \alpha$ in patients with chronic HCV is beneficial remains to be proved. 
Potential novel therapeutic approaches may include the use of anti-TNF $\alpha$ therapy alone or in combination with other established treatments for HCV such as IFN.

\section{Anti-TNF therapy in patients with chronic HCV infection}

Very limited data are available on the use of existing antiTNF agents in patients with chronic HCV infection. Recently, a study of 24 patients with chronic HCV infection and rheumatoid arthritis who received anti-TNF therapy (etanercept or infliximab) has been reported. ${ }^{30}$ No significant adverse events were reported in these patients. No statistically significant changes were noted in the liver aminotransferases or in HCV RNA viral loads yet 16/22 patients with pretreatment and post-treatment HCV RNA measurements showed decline in viral load. ${ }^{30}$ Although limited, this study provides the first assessment of anti-TNF safety in patients with rheumatoid arthritis and will likely be followed up by a prospective assessment of this important clinical question in the management of patients with rheumatoid arthritis infected with HCV.

We recently investigated the safety and efficacy of etanercept in HCV patients as an adjuvant to standard IFN (alfa-2b) and ribavirin through a phase II pilot study. ${ }^{31}$ This was a double blind, placebo controlled, randomised clinical trial in treatment naive adult patients with chronic HCV infection. A total of 50 subjects were randomised to one of two treatment groups (IFN/ribavirin plus etanercept or IFN/ ribavirin plus placebo). HCV genotype 1 infection was found in $90 \%$ of patients. Etanercept (or matched placebo) was given subcutaneously in a dose of $25 \mathrm{mg}$ two times per week for 24 weeks only. The primary endpoints of efficacy were normality of alanine aminotransferase (ALT) and absence of serum HCV RNA at 24 weeks. Safety and tolerability were assessed by direct questioning of patients about side effects, physical examination, laboratory values, and evaluation of premature withdrawal for safety reasons.

More subjects on the etanercept arm met the primary endpoints of normal ALT and absence of serum HCV RNA. The placebo group had fewer patients with negative HCV RNA at 24 weeks than the etanercept group (8/25 (32\%) in the placebo group compared with $12 / 19(63 \%)$ in the etanercept group, $p=0.04)$. Both endpoints of normal ALT and negative HCV RNA were achieved by $7 / 25$ patients $(28 \%)$ on placebo compared with $11 / 19(58 \%)$ in the etanercept group. The difference was statistically significant $(p=0.04)$. No serious adverse effects were noted in this study and no withdrawal due to side effects. Despite the small number of patients in both arms of the study, strong trends were noted with the etanercept group having fewer side effects in almost every category (gastrointestinal, cardiovascular, cutaneous, neurological, and endocrine). Further studies of the role of anti-TNF therapy in hepatitis $\mathrm{C}$ are planned.

On the basis of these limited and preliminary data, antiTNF therapy appears to be safe in patients with chronic HCV infection who are candidates for treatment with these biologically active agents for other coexisting medical conditions such as rheumatoid arthritis. However, monitoring of serum aminotransferases and perhaps HCV RNA during therapy should be considered given the paucity of information and absence of prospectively obtained data. In addition, given the documented increased rate of progression in transplant patients with HCV infection on chronic immunosuppression, it is logical to be concerned about the sequelae of long term immunosuppression in patients with rheumatic disease and HCV infection. Accordingly, we believe that strong consideration be given to baseline liver biopsy prior to the initiation of any long term immunosuppressive regimen. Finally, despite the encouraging results from our phase II randomised clinical trial on the use of anti-TNF therapy as an adjuvant to IFN/ribavirin, this triple treatment may need to be validated in large clinical trials before it can be recommended for routine use in patients with HCV.

\section{HEPATITIS B}

\section{Epidemiology and clinical aspects of chronic HBV infection}

HBV infection represents the commonest form of chronic viral infection in humans with an estimated worldwide burden of 350 million infected individuals. ${ }^{32}$ Approximately 500000 people die each year due to complications of HBV infection. Most chronically infected individuals acquire the virus during birth or early childhood. Exposure to HBV during adulthood is almost invariably followed by virus clearance, indicating a successful host immune response. ${ }^{33}{ }^{34}$

Chronic HBV infection runs through different phases. In most patients who acquire the virus early in life, there is an initial phase of "immune tolerance", characterised by the presence of circulating $\mathrm{HBeAg}$, high levels of serum $\mathrm{HBV}$ DNA and minimal liver inflammation (normal aminotransferases)..$^{33}$ In adults who acquire HBV, this phase is followed by a period of strong host immune response that leads to HBeAg loss and, in some cases, to the development of anti-HBe antibodies ("immune clearance" or HBeAg seroconversion phase). During this phase, immune mediated hepatocellular lysis is prominent with elevated aminotransferase levels and gradually decreasing HBV DNA levels. It has been estimated that most patients clear HBeAg (70-80\%) and progress to a low or non-replicative phase, termed the "inactive carrier state". ${ }^{34}$ In these patients the disease has a benign course with normal aminotransferases, low or undetectable HBV DNA levels, and minimal or absent liver inflammation.

Patients who are not able to clear HBeAg and sustain a strong immune response develop chronic liver necroinflammation that eventually leads to the development of cirrhosis and HCC. This form of chronic hepatitis is designated as "HBeAg positive chronic hepatitis $\mathrm{B}^{\prime \prime} .{ }^{33}$ In a subset of patients (depending mainly on the HBV genotype), mutant HBV strains with deficient or absent HBeAg secretion are selected shortly after or even decades later from the HBeAg seroconversion phase. ${ }^{33}$ These strains are able to replicate, leading to host immune response and liver inflammation (that is, "HBeAg negative chronic hepatitis $\mathrm{B}^{\prime \prime}$ ). This form of hepatitis was thought to be restricted to certain geographical regions, but recent epidemiological data indicate that it is present worldwide. ${ }^{33}$ Regardless of their HBeAg status, a significant proportion of patients with chronic hepatitis $B$ develop cirrhosis and/or HCC (15-40\%) leading to increased mortality. ${ }^{33}$ A number of factors have been linked to the development of these complications including male sex, older age, ongoing HBV replication, elevated aminotransferase levels, alcohol use, and possibly HBV genotype (genotype C).

\section{TNF $\alpha$ and HBV infection}

Serum and hepatic (mainly in infiltrating mononuclear cells) levels of TNF $\alpha$ are increased in patients with acute ${ }^{35-38}$ or chronic $^{39-42}$ hepatitis B. A parallel increase in the expression of the TNF $\alpha$ receptor (p75) in the serum ${ }^{43}$ and hepatocytes ${ }^{36} 39$ of patients with acute or chronic infection has also been noted.

Since TNF $\alpha$ expression is upregulated in different forms of acute or chronic hepatic injury such as hepatitis $\mathrm{C}$ or alcoholic hepatitis, ${ }^{44}$ its specific role in HBV infection has been based mainly on in vitro and animal models of HBV infection. ${ }^{4}$ TNF $\alpha$ produced by HBV specific cytotoxic $\mathrm{T}$ lymphocytes (CTLs) downregulates HBV replication in hepatocytes by non-cytopathic mechanisms in transgenic animal models of 
HBV infection. ${ }^{45}$ Furthermore, animals that do not express $\mathrm{TNF} \alpha$ (TNF $\alpha$ knockout mice) demonstrated defects in the proliferative capacity of their HBV specific CTLs. ${ }^{46}$ These data indicate that $\mathrm{TNF} \alpha$ participates in the specific host immune response against $\mathrm{HBV}$ infection although it remains unclear whether its role is indispensable.

It has also been shown that $\mathrm{TNF} \alpha$ induces hepatocyte apoptosis that is augmented in the presence of HBV infection. ${ }^{47} \mathrm{HBV}$ delivers an apoptotic signal through the diverse actions of the HBx protein, which makes the cells more susceptible to the TNF $\alpha$ induced death signals. ${ }^{48}$ The clinical significance of these in vitro findings, especially in regard to their potential role in hepatocarcinogenesis, so far remains unclear.

\section{Anti-TNF $\alpha$ therapies and HBV infection}

Only three case reports have been published of patients with chronic HBV infection treated with anti-TNF $\alpha$ therapies. The first case was that of a young woman with active Still's disease, chronic HBV infection (HBeAg negative), and transaminasaemia who was given two doses of infliximab $(3 \mathrm{mg} / \mathrm{kg}) .{ }^{49}$ Three weeks after the first infusion, she developed a systemic response with fever, rash, and fulminant hepatitis that ultimately led to liver transplantation. Although the patient had chronic HBV infection, there was no evidence of HBV reactivation (undetectable HBV DNA before and after infliximab treatment) and no evidence of chronic hepatitis in the extracted liver. Thus it is unclear if this fulminant reaction was related to the underlying HBV infection or was a systemic reaction to drug administration.

In the second case, a young man with $\mathrm{HBeAg}$ negative chronic hepatitis B and ankylosing spondylitis initially received antiviral treatment for one year (lamivudine); for another year this was combined with infliximab infusions..$^{50}$ During the combined administration of the two medications there was no evidence of HBV reactivation or hepatitis.

The third case was that of a patient with rheumatoid arthritis and chronic hepatitis B who developed hepatitis B reactivation while on combination therapy with infliximab and methotrexate for 18 months. ${ }^{51}$ The patient responded well to drug discontinuation and antiviral treatment with lamivudine.

In our experience, coadministration of antiviral therapy in patients receiving anti-TNF therapy has not been associated with HBV reactivation or exacerbation of hepatitis. The course of chronic HBV infection and serum levels of ALT in a patient with severe rheumatoid arthritis given anti-TNF therapies (infliximab or etanercept) together with lamivudine is depicted in fig 1 (D Vassilopoulos, S J Hadziyannis, unpublished data).

Concerns have been raised regarding the use of immunomodulatory therapies in patients with chronic HBV infection, based on the increased incidence of HBV reactivations in patients who have received immunosuppressive or cytotoxic therapies. ${ }^{52}$ Rebound HBV replication in hepatocytes after discontinuation of immunosuppressive therapy followed by an unopposed localised cellular immune response in the liver is the presumed pathophysiological sequence of events. Recent guidelines from the European Association for the Study of the Liver (EASL) International Consensus Conference on Hepatitis B suggest that antiviral therapy should be given two to four weeks prior to the initiation of immunosuppressive therapy or if hepatitis develops in this group of patients. ${ }^{53}$ The duration of administration of the antiviral therapy depends on the duration of the immunosuppressive therapy. For patients who receive a short course of therapy, antiviral treatment should be continued for three to six months after completion of therapy. It is unclear what the choice and duration of antiviral therapy should be for

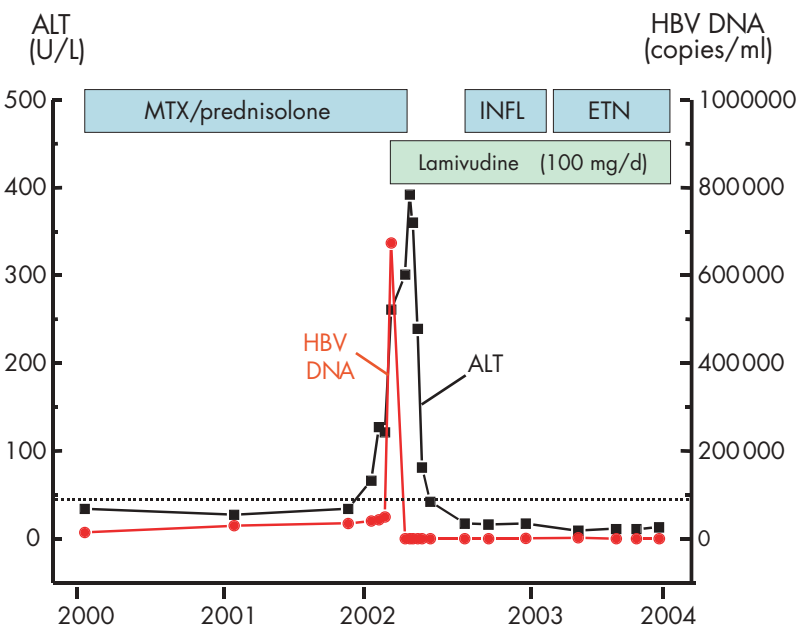

Figure 1 A 58 year old woman with severe seropositive rheumatoid arthritis and chronic hepatitis B infection ( $\mathrm{HBeAg}$ negative) was treated initially with methotrexate (MTX, $15 \mathrm{mg}$ per week) and low dose prednisolone ( $<7.5 \mathrm{mg}$ per day) without significant improvement of the joint disease. During treatment the hepatitis B infection exacerbated and was successfully managed with antiviral therapy (lamivudine $100 \mathrm{mg}$ per day) and discontinuation of MTX and corticosteroids. After biochemical and virological remission was achieved, the patient was given infliximab (INFL, intravenous $3 \mathrm{mg} / \mathrm{kg}$ every eight weeks) for approximately six months. Despite the absence of hepatitis flare, infliximab was replaced with etanercept (ETN, $25 \mathrm{mg}$ subcutaneously twice a week) due to resistant joint disease. The patient had a partial response to this regimen and she is still receiving etanercept and lamivudine without any evidence of biochemical or virological relapse. HBV DNA was measured with the Amplicor HBV monitor assay (Roche Molecular Systems, Nutely, NJ; sensitivity: 400 copies/ml). ALT, alanine aminotransferase.

patients who require lifelong immunosuppressive therapy (as is the case for most patients with inflammatory arthritides).

On the basis of these limited pathophysiological and clinical data, a few suggestions can be made. All patients who are candidates for anti-TNF based therapies should be screened for HBV infection. If chronic HBV infection is diagnosed, further evaluation to define the status of the chronic infection (HBeAg positive/negative chronic hepatitis $v$ inactive carrier state) is warranted. For patients with chronic hepatitis, a hepatologist needs to be consulted for the selection of the appropriate antiviral therapy and the decision to take a pretreatment liver biopsy. For patients with inactive disease, antiviral therapy should probably be administered prior to the initiation of anti-TNF therapy. The duration and type of antiviral therapy for these patients remains to be defined. Regardless of the administered therapy, close follow up with liver function tests and evaluation of viral load is imperative for this group of patients.

\section{HIV INFECTION}

\section{TNF $\alpha$ blockade and HIV infection}

HIV has infected an estimated 40 million people worldwide with nearly 1.5 million in North America and western Europe. ${ }^{54}$ Mortality due to HIV infection increased by an average of $16 \%$ per year between 1987 and 1994 before levelling off in 1995. Since then mortality has fallen dramatically although it has recently levelled off. These improvements in mortality have been attributed to multiple factors but for the most part are due to advances in therapy as nearly $40 \%$ of patients in North America and western Europe are being treated with combination antiretroviral therapy often referred to as HAART (highly active antiretroviral therapy). ${ }^{55} \mathrm{~A}$ wide variety of rheumatic disorders have been 
documented in the presence of HIV infection including inflammatory arthritis, reactive arthritis, myositis, vasculitis, and a spectrum of papulosquamous skin disorders including psoriasis vulgaris as well as pustular psoriasis. ${ }^{56}$ The treatment of these non-suppurative inflammatory disorders in the setting of active HIV infection has been problematic since the population is by definition immunocompromised. Anecdotal reports of serious infection arising in the setting of nonspecific immunosuppression with drugs such as methotrexate have tempered enthusiasm for such approaches. It would appear, however, that many of these earlier reports of immunosuppression related toxicity reflect a state of advanced pre-existing immunosuppression and lack of effective therapy in the pre-HAART era. Today HAART therapy appears to have served the dual purpose of controlling viral replication and inducing immune reconstitution and reducing the frequency and severity of some of the rheumatic complications. Finally, patients who have experienced immune reconstitution on HAART therapy may be more capable of tolerating necessary degrees of immunosuppression not possible in the pre-HAART era.

\section{TNF $\alpha$ and HIV infection}

$\mathrm{TNF} \alpha$ may be intimately involved in the pathogenesis of HIV infection contributing to HIV propagation, lymphocyte depletion, and possibly some clinical manifestations of the disease. HIV infection induces TNF $\alpha$ expression in culture, and exogenous TNF $\alpha$ enhances HIV expression possibly through the actions of nuclear factor (NF)- $\kappa B .{ }^{57}$ In addition to the potential of serving as an important autocrine growth factor, TNF $\alpha$ may also contribute to increased programmed cell death among activated CD4 cells contributing to the progressive immunodeficiency state. TNF $\alpha$ levels have been shown to correlate with HIV-1 RNA as well as interleukin (IL) -6 levels. ${ }^{58}$

Elevated TNF $\alpha$ levels have been observed throughout all stages of HIV infection, with the highest levels detected in the setting of concomitant opportunistic infections such as $M$. tuberculosis tuberculosis. ${ }^{59}$ In patients with HIV-l infection excessive $\mathrm{TNF} \alpha$ expression may serve to accelerate disease and further the loss of immunocompetency as well as contribute to clinical manifestations such as wasting and fever. ${ }^{60}$ Thus for a variety of reasons strategies to inhibit TNF $\alpha$ in the setting of HIV infection have been theoretically appealing though troubling, keeping in mind the essential role for $\mathrm{TNF} \alpha$ in the host defence against intracellular pathogens.

\section{Trials of anti-TNF therapy in the setting of HIV infection}

Thalidomide is an immunomodulator with weak anti-TNF $\alpha$ properties. When administered in combination with antituberculous therapy in patients coinfected with M. tuberculosis thalidomide has been shown to be associated with declining TNF $\alpha$ and HIV RNA levels. ${ }^{61}$ Pentoxifylline, another weak inhibitor of $\mathrm{TNF} \alpha$, when administered to patients with HIV infection and tuberculosis was similarly associated with diminished HIV RNA levels and a more rapid rise in haemoglobin. ${ }^{62}{ }^{63}$ Reduced TNF $\alpha$ levels, however, could not be documented. More recently in a randomised controlled clinical trial in patients with HIV infection and oral aphthosis (which complicates HIV disease), thalidomide was associated with dramatic healing but $\mathrm{TNF} \alpha$ levels did not decline in serum. ${ }^{64}$ The mechanisms through which these weak TNF $\alpha$ inhibitors operate in the setting of HIV infection are at present not clear.

To date three controlled trials of anti-TNF $\alpha$ based therapies in patients with HIV infection have been reported. The first report was a small study of safety, tolerability, and preliminary efficacy in six patients with HIV infection and CD4 cell counts less than $200 / \mathrm{mm}^{3}$ given two infusions of infliximab at $10 \mathrm{mg} / \mathrm{kg}$ two weeks apart. Serum TNF $\alpha$ levels fell but no change in CD4 cell count or plasma HIV RNA was observed and there were no untoward events. ${ }^{65}$ The second study examined the therapeutic effect of a single dose of etanercept $(10 \mathrm{mg})$ in 11 patients on stable HAART, six of whom were also given recombinant IL-2 in an effort to block IL-2 associated immune activation. Pretreatment with etanercept appeared to block both IL-2 induced IL-6 and C-reactive protein responses with no effects on plasma HIV RNA; no severe adverse reactions were attributed to etanercept. ${ }^{66}$ Finally in a recent, extremely intriguing, study by Wallis et al, ${ }^{67} 16$ patients with HIV-1 infection, CD4 counts $>200$ cells $/ \mathrm{mm}^{3}$, and sputum smear positive tuberculosis were treated with twice weekly etanercept $(25 \mathrm{mg})$ in addition to standard antituberculous therapy starting on day 4 and continuing for four weeks. At the time anti-HIV therapy was unavailable and was not included in the regimen. A historical control group on antituberculous therapy alone followed for similar endpoints was used for comparison. The rationale for this study was the belief that excessive TNF $\alpha$ in tuberculosis accompanying HIV infection is responsible for many of the clinical manifestations of the illness as well as the accelerated CD4 cell loss observed in this setting. While statistically the study had low power, trends towards superior responses to tuberculosis treatment including radiographic scoring, time to sputum culture conversion and performance scores were observed in the etanercept group. No adverse events were observed. The investigators concluded that etanercept could be administered during the early stages of treatment for pulmonary tuberculosis but made no conclusions regarding pathophysiological mechanisms or whether this was a drug or class effect.

\section{TNF blockade in the treatment of rheumatic complications in patients with HIV infection}

While rheumatoid arthritis is distinctly rare in the setting of HIV disease, seronegative arthropathies including reactive arthritis and psoriatic arthritis are not, making the question of the safety and efficacy of anti-TNF $\alpha$ therapy clinically relevant. For a variety of reasons clinicians have been reluctant to subject immunosuppressed patients with underlying HIV infection to further immunosuppressive therapies in the absence of other therapeutic options. As noted above, early anecdotal reports of the "induction" of opportunistic infections with drugs such as low dose glucocorticoids and methotrexate have served to fuel this position. In retrospect this probably reflects a combination of exposing undertreated patients with HIV infection (that is, with antiretrovirals and antimicrobial prophylaxis) and some degree of overcaution. Both the experience of successfully treating patients with HIV infection and non-Hodgkin's lymphoma and successful therapeutic trials demonstrating little in the way of untoward toxicity with agents such as high dose glucocorticoids, ${ }^{68}$ low dose ciclosporin, ${ }^{69}$ and cyclophosphamide ${ }^{70}$ show that potent immunosuppressives can be used under controlled circumstances with appropriate caution and observation.

Only two reports of treatment of patients with HIV infection and established rheumatic complications have been published to date. Aboulafia and colleagues ${ }^{71}$ described a patient with advanced HIV infection with CD4 cell counts of less than $50 / \mathrm{mm}^{3}$ who was treated with etanercept for severe psoriatic arthritis refractory to conventional therapy. There was dramatic improvement in both skin and joints, but unfortunately the course of disease was complicated by frequent polymicrobial infections, including Stenotrophomas maltophilia and Pseudomonas aeruginosa. The second case was described by Gaylis ${ }^{72}$ who treated a 41 year old man with HIV 
infection and severe reactive arthritis with constitutional and extensive nail and skin changes who failed to respond to methotrexate $20 \mathrm{mg}$ per week and prednisone $20 \mathrm{mg}$ per day. He was started on infliximab infusions at $3 \mathrm{mg} / \mathrm{kg}$ at 0,2 , and every 6-7 weeks thereafter. The patient had non-detectable HIV RNA at initiation of infliximab therapy and this remained throughout the course of treatment. Dramatic improvement in the joints and skin was noted and methotrexate was gradually tapered.

In summary, experience in treating individuals with HIV infection with anti-TNF based therapies is limited but collectively suggests that such therapies may be given with a reasonable ratio of benefits to risks if the patients' underlying infections are controlled and they are not severely immunosuppressed.

\section{Authors' affiliations}

L H Calabrese, Department of Rheumatic and Immunologic Disease, Cleveland Clinic Foundation, Cleveland, Ohio, USA

N Zein, Department of Gastroenterology, Cleveland Clinic Foundation, Cleveland, Ohio, USA

D Vassilopoulos, Hippokration General Hospital, Athens University School of Medicine, Athens, Greece

Correspondence to: L H Calabrese, Department of Rheumatic and Immunologic Disease, Cleveland Clinic Foundation, 9500 Euclid Ave, Cleveland Ohio 44195; calabr|@ccf.org

\section{REFERENCES}

1 Schluter D, Deckert M. The divergent role of tumor necrosis factor receptors in infectious diseases. Microbes Infect 2000:2:1285-92.

2 Safety update on TNF-a antagonists: infliximab and etanercept. Food and Drug Administration, Arthritis Drugs Advisory Committee, 17 August 2001. Available at: www.fda/gov/ohrms/dockets/ac/01/transcripts/ 3779+2 01.pdf (accessed 29 July 2004).

3 Ellerin T, Rubin RH, Weinblatt ME. Infections and anti-tumor necrosis factor alpha therapy. Arthritis Rheum 2003;48:3013-22.

4 Herbein G, O'Brien WA. Tumour necrosis factor (TNF)-alpha and TNF receptors in viral pathogenesis. Proc Soc Exp Biol Med 2000;223:241-57.

5 Choo QL, Kuo G, Weiner AJ, Overby LR, Bradley DW, Houghton M. Isolation of a cDNA clone derived from a blood-borne non- $A$, non- $B$ viral hepatitis genome. Science 1989;244:359-62.

6 Lavancy D, McMahon B. Worldwide prevalence and prevention of hepatitis C In: Liang TJ, Hoofnagle JH, eds. Hepatitis C. San Diego: Academic Press, 2000:186-201.

7 Alter MJ, Kruszon-Moran D, Nainan OV, McQuillan GM, Gao F, Moyer LA et al. The prevalence of hepatitis $C$ virus infection in the United States, 1988 through 1994. N Engl J Med 1999;341:556-62.

8 El Serag HB. Hepatocellular carcinoma and hepatitis $C$ in the United States. Hepatology 2002;36:S74-S83.

9 Hoofnagle JH. Course and outcome of hepatitis C. Hepatology 2002;36:S21-S29.

10 Fried MW, Shiffman ML, Reddy KR, Smith C, Marinos G, Goncales FL Jr, et al. Peginterferon alfa-2a plus ribavirin for chronic hepatitis $C$ virus infection. N Engl J Med 2002;347:975-82.

11 Hadziyannis SJ, Sette H Jr, Morgan TR, Balan V, Diago M, Marcellin P, et al. Peginterferon-alpha2a and ribavirin combination therapy in chronic hepatitis $C$ : a randomised study of treatment duration and ribavirin dose. Ann Intern Med 2004; 140:346-55.

12 Manns MP, McHutchison JG, Gordon SC, Rustgi VK, Shiffman M, Reindollar $\mathrm{R}$, et al. Peginterferon alfa- $2 \mathrm{~b}$ plus ribavirin compared with interferon alfa-2b plus ribavirin for initial treatment of chronic hepatitis $C$ : a randomised trial. Lancet 2001;358:958-65.

13 Di Bisceglie AM, Hoofnagle JH. Optimal therapy of hepatitis C. Hepatology 2002;36:S121-S127.

14 Lindsay KL. Introduction to therapy of hepatitis C. Hepatology 2002;36:S1 14-S120

15 Diepolder HM, Zachoval R, Hoffmann RM, Wierenga EA, Santantonio T, Jung $M C$, et al. Possible mechanism involving T-lymphocyte response to nonstructural protein 3 in viral clearance in acute hepatitis $C$ virus infection. Lancet 1995;346:1006-7.

16 Tsai SL, Liaw YF, Chen MH, Huang CY, Kuo GC. Detection of type 2-like Thelper cells in hepatitis $C$ virus infection: implications for hepatitis $C$ virus chronicity. Hepatology 1997; 25:449-58.

17 Kamal SM, Fehr J, Roesler B, Peters T, Rasenack JW. Peginterferon alone or with ribavirin enhances $\mathrm{HCV}$-specific CD4 T-helper 1 responses in patients with chronic hepatitis C. Gastroenterology 2002;123:1070-83.

18 Cramp ME, Rossol S, Chokshi S, Carucci P, Williams R, Naoumov NV. Hepatitis $C$ virus-specific T-cell reactivity during interferon and ribavirin treatment in chronic hepatitis C. Gastroenterology 2000;1 18:346-55.
19 Tam RC, Pai B, Bard J, Lim C, Averett DR, Phan UT, et al. Ribavirin polarizes human T cell responses towards a Type 1 cytokine profile. J Hepatol 1999:30:376-82

20 Beutler B, Cerami A. The biology of cachectin/TNF-a primary mediator of the host response. Annu Rev Immunol 1989;7:625-55.

21 Olsson I, Gullberg U, Lantz M, Peetre C. A tumor necrosis factor binding protein (TNF-BP)-physiological antagonist of TNF. Biotherapy 1991;3:159-65.

22 Kallinowski B, Haseroth K, Marinos G, Hanck C, Stremmel W, Theilmann L, et al. Induction of tumour necrosis factor (TNF) receptor type p55 and p75 in patients with chronic hepatitis $\mathrm{C}$ virus (HCV) infection. Clin Exp Immunol 1998;111:269-77.

23 Kishihara Y, Hayashi J, Yoshimura E, Yamaji K, Nakashima K, Kashiwagi S. IL-1 beta and TNF-alpha produced by peripheral blood mononuclear cells before and during interferon therapy in patients with chronic hepatitis C. Dig Dis Sci 1996:41:315-21.

24 Nelson DR, Lim HL, Marousis CG, Fang JW, Davis GL, Shen L, et al. Activation of tumor necrosis factor-alpha system in chronic hepatitis $C$ virus infection. Dig Dis Sci 1997;42:2487-94.

25 Fukuda R, Ishimura N, Ishihara S, Chowdhury A, Morlyama N, Nogami C, et al. Intrahepatic expression of pro-inflammatory cytokine mRNAs and interferon efficacy in chronic hepatitis C. Liver 1996;16:390-9.

26 Larrea E, Garcia N, Qian C, Civeira MP, Prieto J. Tumour necrosis factor alpha gene expression and the response to interferon in chronic hepatitis $\mathrm{C}$. Hepatology 1996;23:210-17.

27 Cope AP, Londei M, Chu NR, Cohen SB, Elliott MJ, Brennan FM, et al. Chronic exposure to tumor necrosis factor (TNF) in vitro impairs the activation of T cells through the T cell receptor/CD3 complex; reversal in vivo by anti-TNF antibodies in patients with rheumatoid arthritis. J Clin Invest 1994;94:749-60.

28 Maurice MM, van der Graaff WL, Leow A, Breedveld FC, van Lier RA, Verweii CL. Treatment with monoclonal anti-tumor necrosis factor alpha antibody results in an accumulation of Th $1 \mathrm{CD} 4+\mathrm{T}$ cells in the periphera blood of patients with rheumatoid arthritis. Arthritis Rheum 1999;42:2166-73.

29 Berg L, Lampa J, Rogberg S, van Vollenhoven R, Klareskog L. Increased peripheral $T$ cell reactivity to microbial antigens and collagen type II in rheumatoid arthritis after treatment with soluble TNFalpha receptors. Ann Rheum Dis 2001;60:133-9.

30 Peterson JR, Hsu FC, Simkin PA, Wener MH. Effect of tumour necrosis factor alpha antagonists on serum transaminases and viraemia in patients with rheumatoid arthritis and chronic hepatitis C infection. Ann Rheum Dis 2003;62:1078-82.

31 Zein NN. A phase II randomised, double blind, placebo controlled study of tumor necrosis factor antagonist (Etanercept, Enbrel) as an adjuvant to interferon and ribavirin in naive patients with chronic hepatitis $C$ [abstract] Hepatology 2002;36:504A.

32 Alter MJ. Epidemiology of hepatitis B in Europe and worldwide. $J$ Hepatol 2003:39/suppl 1):S64-S69.

33 Hadziyannis SJ, Vassilopoulos D. Hepatitis B e antigen-negative chronic hepatitis B. Hepatology 2001;34:617-24.

34 Lok AS, McMahon BJ. Chronic hepatitis B. Hepatology 2001;34:1225-41.

35 Monsalve-De Castillo F, Romero TA, Estevez J, Costa LL, Atencio R, Porto L, et al. Concentrations of cytokines, soluble interleukin-2 receptor, and soluble CD30 in sera of patients with hepatitis B virus infection during acute and convalescent phases. Clin Diagn Lab Immunol 2002;9:1372-5.

36 Spengler U, Zachoval R, Gallati H, Jung MC, Hoffmann R, Riethmuller G et al. Serum levels and in situ expression of TNF-alpha and TNF-alpha binding proteins in inflammatory liver diseases. Cytokine 1996;8:864-72.

37 Tang TJ, Kwekkeboom J, Laman JD, Niesters HG, Zondervan PE, de Man RA, et al. The role of intrahepatic immune effector cells in inflammatory liver injury and viral control during chronic hepatitis B infection. J Viral Hepat 2003; 10:159-67.

38 Torre D, Zeroli C, Giola M, Ferrario G, Fiori GP, Bonetta G, et al. Serum levels of interleukin-1 alpha, interleukin-1 beta, interleukin-6, and tumor necrosis factor in patients with acute viral hepatitis. Clin Infect Dis 1994;18:194-8.

39 Fang JW, Shen WW, Meager A, Lau JY. Activation of the tumor necrosis factor-alpha system in the liver in chronic hepatitis B virus infection. Am J Gastroenterol 1996;91:748-53.

40 Hussain MJ, Lau JY, Williams R, Vergani D. Hepatic expression of tumour necrosis factor-alpha in chronic hepatitis B virus infection. J Clin Pathol 1994;47:1112-15.

41 Sheron N, Lau J, Daniels H, Goka J, Eddleston A, Alexander GJ, et al Increased production of tumour necrosis factor alpha in chronic hepatitis B virus infection. J Hepatol 1991;12:241-5.

42 Yoshioka K, Kakumu S, Arao M, Tsutsumi Y, Inoue M, Wakita T, et al. Immunohistochemical studies of intrahepatic tumour necrosis factor alpha in chronic liver disease. J Clin Pathol 1990;43:298-302.

43 Marinos G, Naoumov NV, Rossol S, Torre F, Wong PY, Gallati H, et al. Tumour necrosis factor receptors in patients with chronic hepatitis $B$ virus infection. Gastroenterology 1995;108:1453-63.

44 Diehl AM. Cytokine regulation of liver injury and repair. Immunol Rev 2000;174:160-71

45 Guidotti LG, Ishikawa T, Hobbs MV, Matzke B, Schreiber R, Chisari FV. Intracellular inactivation of the hepatitis B virus by cytotoxic $T$ lymphocytes. Immunity 1996;4:25-36.

46 Kasahara S, Ando K, Saito K, Sekikawa K, Ito H, Ishikawa T, et al. Lack of tumor necrosis factor alpha induces impaired proliferation of hepatitis $B$ virus specific cytotoxic T lymphocytes. J Virol 2003;77:2469-76. 
47 Su F, Schneider RJ. Hepatitis B virus $H B x$ protein sensitizes cells to apoptotic killing by tumor necrosis factor alpha. Proc Natl Acad Sci U S A 1997;94:8744-9.

48 Kim KH, Seong BL. Pro-apoptotic function of HBV X protein is mediated by interaction with c-FLIP and enhancement of death-inducing signal. EMBO J 2003;22:2104-16.

49 Michel M, Duvoux C, Hezode C, Cherqui D. Fulminant hepatitis after infliximab in a patient with hepatitis B virus treated for an adult onset Still's disease. J Rheumatol 2003;30:1624-5.

50 Oniankitan O, Duvoux C, Challine D, Mallat A, Chevalier X, Pawlotsky JM, et al. Infliximab therapy for rheumatic diseases in patients with chronic hepatitis B or C. J Rheumatol 2004;31:107-9.

51 Ostuni $\mathbf{P}$, Botsios $C$, Punzi L, Sfriso $P$, Todesco $S$. Hepatitis $B$ reactivation in a chronic hepatitis $B$ surface antigen carrier with rheumatoid arthritis treated with infliximab and low dose methotrexate. Ann Rheum Dis 2003;62:686-7.

52 Vento S, Cainelli F, Longhi MS. Reactivation of replication of hepatitis B and C viruses after immunosuppressive therapy: an unresolved issue. Lancet Oncol 2002;3:333-40.

53 de Franchis R, Hadengue A, Lau G, Lavanchy D, Lok A, Mclntyre N, et al. EASL International Consensus Conference on Hepatitis B. 13-14 September 2002, Geneva, Switzerland. Consensus statement (long version). J Hepatol 2003;39(suppl 1):S3-25.

54 UNAIDS/WHO. Report on the global HIV/AIDS epidemic. Joint United Nations Programme on HIV/AIDS, 2002. Available at www.UNAIDS.ORG/ BANGKOK2004/report.html (accessed 29 July 2004).

55 Palella FJ Jr, Delaney KM, Moorman AC, Loveless MO, Fuhrer J, Satten GA, et al. Declining morbidity and mortality among patients with advanced human immunodeficiency virus infection. HIV Outpatient Study Investigators. N Engl J Med 1998;338:853-60.

56 Vassilopoulos D, Calabrese LH. Rheumatic aspects of human immunodeficiency virus infection and other immunodeficient states. In: Hochberg MC, Silman AJ, Smolen JS, Weinblatt ME, Weisman MH, eds. Rheumatology. London: Mosby, 2003:1 115-29.

57 Duh EJ, Maury WJ, Folks TM, Fauci AS, Rabson AB. Tumour necrosis factor alpha activates human immunodeficiency virus type 1 through induction of nuclear factor binding to the NF-kappa B sites in the long terminal repeat. Proc Natl Acad Sci U S A 1989:86:5974-8.

58 Dezube BJ, Lederman MM, Chapman B, Georges DL, Dogon AL, Mudido P, et al. The effect of tenidap on cytokines, acute-phase proteins, and virus load in human immunodeficiency virus (HIV)-infected patients: correlation between plasma HIV-1 RNA and proinflammatory cytokine levels. J Infect Dis 1997; 176:807-10.

59 Whalen C, Horsburgh CR, Hom D, Lahart C, Simberkoff M, Ellner J. Accelerated course of human immunodeficiency virus infection after tuberculosis. Am J Respir Crit Care Med 1995;151:129-35.
60 Valdez H, Lederman MM. Cytokines and cytokine therapies in HIV infection. AIDS Clin Rev 1997:187-228.

61 Marriott JB, Cookson S, Carlin E, Youle M, Hawkins DA, Nelson M, et al. A double-blind placebo-controlled phase II trial of thalidomide in asymptomatic HIV-positive patients: clinical tolerance and effect on activation markers and cytokines. AIDS Res Hum Retroviruses 1997;13:1625-31.

62 Paterson DL, Georghiou PR, Allworth AM, Kemp RJ. Thalidomide as treatment of refractory aphthous ulceration related to human immunodeficiency virus infection. Clin Infect Dis 1995;20:250-4.

63 Wallis RS, Nsubuga P, Whalen C, Mugerwa RD, Okwera A, Oette D, et al. Pentoxifylline therapy in human immunodeficiency virus-seropositive persons with tuberculosis: a randomised, controlled trial. J Infect Dis 1996; 174:727-33

64 Jacobson JM, Greenspan JS, Spritzler J, Ketter N, Fahey JL, Jackson JB, et al. Thalidomide for the treatment of oral aphthous ulcers in patients with human immunodeficiency virus infection. National Institute of Allergy and Infectious Diseases AIDS Clinical Trials Group. N Engl J Med 1997;336:1487-93.

65 Walker RE, Spooner KM, Kelly G, McCloskey RV, Woody JN, Falloon J, et al. Inhibition of immunoreactive tumor necrosis factor-alpha by a chimeric antibody in patients infected with human immunodeficiency virus type 1 . $J$ Infect Dis 1996;174:63-8.

66 Sha BE, Valdez H, Gelman RS, Landay AL, Agosti J, Mitsuyasu R, et al. Effect of etanercept (Enbrel) on interleukin 6, tumor necrosis factor alpha, and markers of immune activation in HIV-infected subjects receiving interleukin 2. AIDS Res Hum Retroviruses 2002;18:661-5.

67 Wallis RS, Kyambadde P, Johnson JL, Horter L, Kittle R, Pohle M, et al. A study of the safety, immunology, virology, and microbiology of adjunctive etanercept in HIV-1-associated tuberculosis. AIDS 2004; 18:257-64.

68 Wallis RS, Kalayjian R, Jacobson JM, Fox L, Purdue L, Shikuma CM, et al. A study of the immunology, virology, and safety of prednisone in HIV-1-infected subjects with CD4 cell counts of 200 to $700 \mathrm{~mm}^{3}$. J Acquir Immune Defic Syndr 2003;32:281-6.

69 Calabrese LH, Lederman MM, Spritzler J, Coombs RW, Fox L, Schock B, et al. Placebo-controlled trial of cyclosporin-A in HIV-1 disease: implications for solid organ transplantation. J Acquir Immune Defic Syndr 2002;29:356-62.

70 Bartlett JA, Miralles GD, Sevin AD, Silberman M, Pruitt SK, Ottinger J, et al. Addition of cyclophosphamide to antiretroviral therapy does not diminish the cellular reservoir in HIV-infected persons. AIDS Res Hum Retroviruses 2002; 18:535-43.

71 Aboulafia DM, Bundow D, Wilske K, Ochs Ul. Etanercept for the treatment of human immunodeficiency virus-associated psoriatic arthritis. Mayo Clin Proc 2000;75:1093-8.

72 Gaylis N. Infliximab in the treatment of an HIV positive patient with Reiter's syndrome. J Rheumatol 2003;30:407-11. 